\section{Medical and Biological Compilation}

THE second edition of "Current Indexing and Abstracting Periodicals in the Medical and Biological Sciences" attempts to provide an annotated list of all the most important indexing and abstracting periodicals in medicine and the allied sciences published currently throughout the world, and the number of titles has been increased from 142 in the first (1953) edition to 310 (World Health Organization. Library News, Vol. 12, Supplement 2. Pp. 85. Geneva: World Health Organization, 1959). In general annual publications containing review articles are excluded, but the yearbook series, containing the abstracts, are included. Periodicals are listed alphabetically by title, with the name and address of the publisher and/or responsible organization, first year of publication, current subscription price, year and volume number of the first volume in the World Health Organization holding, frequency of publication, number of periodicals regularly scrutinized and of abstracts or title entries published annually.

\section{Transvaal Museum}

THIs active museum publishes both a Bulletin and Annals. The former for January 1960, No. 4, includes some notes on mammal specimens as museum material and the collecting expedition of Colonel Jack Scott to Somalia. A short article also describes the birdlife at Sandwich Harbour. The April issue of the Annals $(14$, Part 1 ; 1960) contains an important key to the genera of South African freshwater and estuarine gastropods, observations on the locomotion of the South African adder, Bitis peringueyi, and on the early post-natal development of multi-mammate mice. The dibatag, Ammodorcas clarkei, is also dealt with in an important illustrated paper by Mr. J. Meester.

\section{Psychiatric Services and Architecture}

A воOKLet published by the World Health Organization attempts an analysis, not only of the planning and management of psychiatric hospitals, but also of the structure and function of other psychiatric services such as ouc-patients' departments, psychiatric wards in general hospitals, rehabilitation facilities, and other mental health services (Public Health Papers, No. 1 : Psychiatric Services and Architecture. By A. Baker, R. Llewelyn Davies and P. Sivadon. Pp. 59. Geneva: World Health Organization; London: H.M. Stationery Office, 1959. 2 Swiss francs; $3 s .6 d$.). It is the joint work of two psychiatrists and an architect who has specialized in hospital architecture, but it also takes account of the comments and suggestions of twenty-nine other psychiatrists and four architects from other countries. It reprefents an international approach to the problem of how psychiatric services can best be organized in the interests of the patients and be given suitable architectural expression. The types of buildings proposed are very different from the gloomy, prison-like mansions which until recently were regarded in many parts of the world as the only appropriate places in which to incarcerate mental patients ; the epproach to the patient is based upon the desire to re-integrate him into society with all possible speed, and to provide him with surroundings that will contribute to that end.

\section{Roe Deer}

Two of Britain's native deer, the red and the roe, have been known to inhabit the country since pre- historic times. The roe is now more widely distributed in England than the red, but, in Scotland, the red deer is the more widespread species. There are few, if any, in Wales, and none in Ireland. Because there are no predatory animals to keep these deer in reasonable numbers, the burden of doing this rests on the owners of the land on which they live. As the planted forests grow taller the problem of control will increase, and it is important that game-keepers and foresters should be familiar with their habits. To help them, the Forestry Commission has produced anothor of its attractive illustrated booklets, on the roe deer, which would be equally useful for natural history lessons in schools (Leaflet No. 45: The Roe Deer. Pp. 16. (London: H.M. Stationery Office, 1960.) 1s. 6d. net). It describes not only methods of control but also how these attractive animals may be stalked, the terms of venery, the calls of the roe, and, not least attractive, a suggested method of cooking roast haunch of roe.

\section{A New British Transistorized Computer}

Througr the joint enterprise of the General Electric Company and International Computers and Tabulators, Ltd., 149 Park Lane, London, W.1, a new, fully transistorized, automatic digital computer, the 1301, has been produced. This machine has characteristics which place it in the front rank of the large British computers which are available at the present time. It has storage, both on magnetic cores and on drums, the former in units of 400 words ; the latter in units of 12,000 words ; magnetic tape transports and a high-speed line-at-a-time printer are also available. The arithmetical speeds of the machine are such that addition and like operations take about $25 \mu$ sec., and multiplication about eight times as much. These fast operating speeds are achieved with the remarkably low pulse-operating time of $1 \mathrm{Mc} / \mathrm{s}$. ; this is apparently due to the unusual feature of the machine, namely, that it operates in serio-parallel decimal code, each decimal digit being represented by signals on four lines in parallel and each computer word consisting of twelve decimal digits. Probably the most surprising feature of the machine is its low power consumption, which the makers state to be only $4 \mathrm{~kW}$. In common with most recently produced machines, a comprehensive range of sub-routines and automatic programming facilities is also evailable. Because it is built with magnetic tape as a standard and planned-for ancillary, this machine is more attractive than many of the British machines of the immediate past, in which the later addition of magnetic tape has only been achieved by considerable alterations.

\section{Rock Pressure and Earthquakes}

WHEREAS the virgin pressure of the fluids in rock formations at depth can be measured readily, the pressure in the solid rock itself could not, until recently, be measured directly. In practical problems concerned with mining and deep drilling it has been customary to assume that the pressure is satisfactorily defined by the weight of overburden. A method of direct measurement has been developed in Sweden which shows that this assumption is too simple. The method and results are described by Nils Hast in a recent issue of Sveriges Geologiska Undersökning (Ser. C, No. 560 : The Measurement of Rock Pressure in Mines. By Nils Hast. Pp. 183. Stockholm : Sveriges Geologiska Undersökning, 1958). 